JECED : Journal of Early Childhood Education and Development Homepage : http://jurnalftk.uinsby.ac.id/index.php/JCED

P-ISSN : 2715-8454 ; E-ISSN : 2715-8446 JECED, Vol. 3, No. 1, Juni 2021 (47-52) Email : jeced@uinsby.ac.id

\title{
Pemahaman Guru PAUD Tentang Pembelajaran Berbasis STEAM dengan Penggunaan Media Loose Parts di Desa Bukit Harapan
}

\author{
Nurul Qomariyah, Zahratul Qalbi
}

Universitas Bengkulu, Bengkulu, Indonesia

DOI : https://doi.org/10.15642/jeced.v3i1.995

\begin{abstract}
This study aims to describe the level of understanding of PAUD teachers or PAUD educators about loose parts games. The research method used is qualitative, using the method of direct interviews with early childhood teachers in Bukit Harapan Village, Pinang Raya District, North Bengkulu Regency. The sample used is 3 teachers who teach in one of the PAUD schools. From the results of the interview, it was found that the teacher did not understand the loose parts game. And schools have not applied STEAM-based learning by using learning media in the form of loose parts. So that to overcome the lagging behind modern learning, the teachers at these schools will try to find information about STEAM-based learning so that they can keep up with the times and children's creativity can also be maximized.
\end{abstract}

Article Info

Article history:

Received: January 20, 2021

Approved: June 29, 2021

Published online: June 30, 2021

Keywords:

STEAM

Loose parts

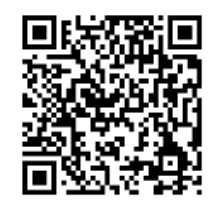

\begin{abstract}
Abstrak
Penelitian ini bertujuan untuk mendeskripsikan tingkat pemahaman guru PAUD atau pendidik PAUD tentang permainan loose parts. metode penelitian yang digunakan adalah kualitatif, dengan menggunakan metode wawancara langsung terhadap guru PAUD di desa Bukit Harapan, Kecamatan Pinang Raya, Kabupaten Bengkulu Utara. Sampel yang digunakan sebanyak 3 orang guru yang mengajar di salah satu sekolah PAUD. Dari hasil wawancara di dapatkan bahwa guru belum memahami tentang permainan loose parts tersebut. Dan sekolah juga belum mengaplikasikan pembelajaran berbasis STEAM dengan penggunaan media pembelajaran berupa loose parts. Sehingga untuk mengatasi tertinggalnya pembelajaran yang modern guru-guru disekolah tersebut akan berusaha mencari informasi tentang pembelajaran berbasis STEAM agar dapat mengikuti perkembangan zaman dan kreativitas anak juga dapat tergali dengan maksimal.
\end{abstract}

\section{Informasi Artikel}

Riwayat Artikel

Diterima: 20012021

Disetujui: 29062021

Publikasi online: 30062021

\section{Kata kunci:}

STEAM

Loose parts 


\section{PENDAHULUAN}

Pendidikan di abad 21 yang telah memasuki era disrupsi dan era revolusi industri 4.0 dituntut untuk terus berinovasi. Pendidikan Anak Usia Dini (PAUD) sebagai salah satu lembaga pendidikan dasar, harus bersiap untuk menjawab tantangan perkembangan zaman. PAUD dituntut pula untuk melakukan perubahan baik dari kurikulum maupun pembelajaran. Anak-anak yang belajar di PAUD harus dibekali dengan berbagai macam keterampilan (hard skills dan soft skills) untuk dapat beradaptasi dengan perubahan yang terjadi di sekelilingnya. Keterampilan yang perlu diajarkan pada anak yaitu keterampilan berpikir kritis, berpikir kreatif (kreativitas), kerja sama, dan komunikasi selain tentunya anak belajar mengenai pengetahuan (pengetahuan fisik, logika matematika, dan sosial). Keterampilan-keterampilan tersebut harus dilakukan secara terintegrasi dalam proses pembelajaran.

Mutiah (2010) menjelaskan makna bermain merupakan kegiatan yang sangat penting bagi pertumbuhan dan perkembangan anak. bermain harus dilakukan atas inisiatif anak dan keputusan anak itu sendiri. Bermain harus dilakukan dengan rasa senang, sehingga semua kegiatan bermain yang menyenangkan akan menghasilkan proses belajar pada anak.

Berdasarkan hasil penelitian yang dilakukan Melani (2015) bahwa bermain pembangunan merupakan aktivitas yang melibatkan anak untuk melakukan proses belajar nyata melalui kegiatan bermai yang dapat mengembangkan kemampuan motorik halus anak usia dini.

Menurut Toedjasaputra (2011) bernain pembangunan yaitu kegiatan yang menggunakan berbagai benda yang ada untuk menciptakan suatu hasil karya tertentu. Hal ini sejalan dengan pendapat Mountulalu, et. al (2009) yang menyatakan bermain pembangunan merupakan bentuk permainan aktif yang di mana anak membangun sesuatu dengan mempergunakan bahan atau alat permaianan.

Permainan yang sekarang sedang hangat di kalangan Pendidikan Anak Usia Dini yang berfungsi untuk merangsang kemampuan anak yaitu menggunakan permainan loose parts. Loose parts merupakan bahan-bahan terbuka, terpisah, dapat dijadikan satu kembali, dibawa, digabungkan, dijajar, dipindahkan, dan digunakan sendiri maupun digabung dengan bahan-bahan lain (benda alam maupun sintetis). Loose parts dapat digunakan sebagai bahan pembelajaran STEAM karena sesuai dengan karakteristik anak, dapat diadaptasi dan dimanipulasi dalam banyak cara, mendukung kreativitas dan imajinasi anak, serta mampu untuk mengembangkan ide anak (Siantajani, 2018) sebuah permainan.

Caser dan Robinson, (2016:6) menjelaskan bahwa anak-anak sangat membutuhkan sbuah lingkungan sebagai tujuanmemanipulasi, mengidentifikasi, mengevaluasi, dan menyampaikan gagasan mereka sendiri melalui loose parts anak akan diberikan kesempatan untuk berinteraksi secara langsung dengan lingkungan terdekatnya. Ketika anak bermain menggunakan sbarang lepasan, terbuka anak akan memiliki pemikiran yang mengarah kepada keterampilan berpikir tahapan pemecahan masalah dan penalaran teoritis.

Haughey dan Hill (2017) menyatakan bahwa loose parts merupakan kumpulan benda alam atau benda buatan yang dapat digunaka untuk memancing ide dalam permainan anak. benda-benda ini bersifat terbuka sehingga mendukung perkembangan anak untuk berkarya. Loose parts mendorong anak untul melakukan pengamatan dan penelitian akan benda-benda yang akan digunakan. 
Handyman, Benson, Ullah dan Telfold (2016) mengemukakan manfaat bermain menggunakan loose parts dalam proses pembelajaran antara lain: 1) meningkatkan level permainan kreatif dann imajinatif, 2) anak bermain lebih kooperatif dan mampi bersosialisasi, 3) anak-anak secara fidik lebih aktif, 4) meningkatkan keterampilan komunikasi.

Kiewra dan Vaselek (2016) berpendapat bahwa loose parts merupakan sebuah benda potongan yang bebas dimainkan dan tidak dapat diprediksi akan menjadi apa. Loose part mendukung perkembangan pola pikir anak yang berbeda-beda dan unik. Hal ini dikarenakan loose parts tidak memiliki aturan terikat untuk digunakan, kemungkinan yang dimiliki tidak terbatas dan dapat terus di eksplorasi anak. bahan-bahan terbuka yang dapat ditemukan dimana saja dapat memberi stimulus bagi perkembangan anak untuk mengenali potensi berpikirnya. Anak dapat dengan bebas menentukan akan menjadi apa benda tersebut dan benda mana yang dipilihnya untuk dimainkan.

Dari beberapa teori tersebut dapat disimpulkan bahwa pembelajaran berbasis STEAM dengan penggunaan media Loose Parts ini sangat mendukung perkembangan anak, namun kenyataan di lapangan pengetahuan pendidik PAUD tentang pemainan loose parts masing sangat rendah terutama didaerah pedesaan. Hal ini didukung berdasarkan hasil wawancara yang dilakukan bersama guru PAUD di desa Bukit Harapan, Kecamatan Pinang Raya, Kabupaten Bengkulu utara. Para pendidik di Tk tersebut belum mengetahui tentang permaian loose parts sehingga mereka belum bisa mengaplikasikan permaian loose parts ini pada pembelajaran. Ketidakpahaman pendidik PAUD tentang penggunaan serta pengaplikasian media loose parts ini menjadi salah satu penghambat pendidikan yang harus mengikuti zaman tersebut. Hal ini juga mengambat berbagai kreativitas serta keterampilan anak usia dini yang seharusnya dapat tersalurkan dengan penggunaan media permainan loose parts tersebut.

\section{METODE}

Desain penelitian yag digunakan dalam penelitian ini adalah kualitatif dan fokus memaknai pemahaman guru tentang permainan Loose Parts dengan subjek penelitian berjumlah 3 orang guru di TK Cempaka 1 Bukit Harapan selama 3 hari yaitu 27-29 Desember 2020. Analisis data dilakukan menggunakan deskriptif naratif dimana secara langsung peneliti melakukan wawancara langsung terhadap guru di sekolah tersebut.

\section{HASIL DAN PEMBAHASAN}

Berdasarkan hasil wawancara yang sudah dilakukan dengan pendidik PAUD di Desa Bukit Harapan, beliau mengatakan bahwa untuk saat ini belum dilakukan pembelajaran berbasis STEAM dan penggunaan media loose parts. Responden mengatakan bahwa pembelajaran berbasis STEAM ini belum bisa dilakukan karena terkendala oleh pengetahuan guru dan kurangnya pelatihan-pelatihan yang di adakan di desa tersebut, selain itu juga dari faktor guru yang memang bukan dari pendidikan PAUD melainkan dari pendidikan lain. Namun, responden tetap akan berusaha untuk mengembangkan pembelajaran berbasis STEAM dan akan bekerja sama dengan teman sejawatnya serta akan mendiskusikannya kepala kepala sekolah, karena di rasa pembelajaran ini sangat bermanfaat bagi perkembangan kreativitas anak.

Responden juga menyatakan bahwa untuk di daerah pedesaan tidak mudah untuk mengikuti perkembangan di dunia pendidikan seperti halnya dikota, faktor utama yang juga mempengaruhi ketertinggalnnya yaitu mengenai media yang kurang memadai dan kurangnya kreativitas guru atau pendidik di daerah tersebut dan kurangnya pasrtisipasi 
guru untuk menggali potensi dari pendidik itu sendiri, yang seharusnya media itu dapat diperoleh dari pemanfaatan barang-barang yang ada di sekitarnya ini menjadi terkendala akibat dari kurangnya kreativitas yang dimiliki guru atau pendidik di desa ini.

Dari penjelasan di atas maka berbukti bahwa pemahaman guru tentang permainan loose parts masih rendah dan sangat perlu untuk di ditingkatkan untuk mempersipkan pendidik yang lebih berwawasan dan berdaya kreativitas yang tinggi sesuai dengan seiring perkembangan zaman.

Piaget (2010) mengemukakan bahwa seiring dengan berbagai macam bahan main untuk main pembangunan, koordinasi motorik halus berkembang, dan secara kognisi bergerak mendekati pikiran operasional kongkrit, hasil karya mereka menjadi semakin nyata.

STEM merupakan akronim dari science, Technology, Engineering, Arts, and Mathematic. Model pembelajaran STEAM memiliki dampak terhadap anak usia dini salah satunya yaitu meningkatkan minat siswa dan pemahaman dalam teknologi dan kemampuan untuk memecahkan masalah di dunia nyata (Thunerberg, Salmi, \& Bogner, 2018). Seperti yang dijelaskan oleh Kofac (2017) bahwa STEAM menumat pembelajaran berbasis teknologi ilmiah dan kemampuan dalam memecahkan masalah di dunia nyata.

Selain itu dengan model pembelajaran STEAM mendorong anak unruk mengembangkan rasa ingin tahu, keterbukaan pengalaman (Perignat \& KatzBuonincontro, 2019) dan mengajukan pertanyaan sehingga anak membangun pengetahuan disekitarnya dengan mengeksplorasi, mengamati, menemukan, dan menyelidiki sesuatu yang ada disekitarnya (Munawar, 2019). Fokus STEAM adalah pada menciptakan yaitu produk akhir dan proses pembuatannya. Proses pembuatan lebih penting dibanding produk akhir karena didalam prosesnya terdapat aspek eksplorasi, pemikiran kreatif, desain teknik, ekspresi kreatif, evaluasi dan desain ulang (Peignat \& Katz-Buonicontro, 2019). Dalam proses tersebut, model STEAM dapat mengajarkan anak untuk berproses melalui kegiatan mengamati, bermain, menggali pola, dan melatih keterampilan berpikir kreatif serta keterampilan kerjasama dan komunikasi antar anak dalam menyelesaikan sesuatu tugas atau project yang diberikan oleh guru (Guyotte, K.W., Sochacka, N. W., Costantino, T. E., Walther, J., \& Kellam, 2014) selain itu dalam proses anak dituntut untuk berpikir kreatif dan kritis pada hal-hal yang baru didapat oleh anak. anak juga terdorong untuk memecahkan masalah bersama teman sebayanya (Michaud, 2014).

Dalam pendidikan yang tujuannya adalah memberdayakan anak-anak untuk meningkatkan dunia mereka sendiri, dimulaisejak dini. Sebagaimana diungkapkan oleh Setyowati, I (2011) menyatakan bahwa kegiatan belajar mengajar harus dapat membekali peserta didik dengan kecakapan hidup (life skill) yang sesuai dengan lingkungan kehidupan dan kebutuhan peserta didik sesuai jamannya, sehingga pendidikan itu bermanfaat bagi anak-anak dengan membuat mereka berpikir lebih efektif (dan jauh lebih praktis), memberdayakan anak-anak untuk bertindak dan berhubungan secara efektif didunia.

Kurikulum 2013 PAUD dengan tematik integrative dan pendekatan saintifik sanagt cocok untuk memadukan pembelajaran berbasis STEAM, karena pembelajaran dilaksanakan dengan menggunakan berbagai konteks dapat mendekatkan materi pelajaran dengan kehidupan sehari-hari atau tema yang dekat dengan dunia anak. pendekatan inilah yang saat ini sedang dibangun kembali negara-negara maju, salah satunya yaitu pendekatan STEAM (science, tehnology, engineering, art, and mathematics). 
Senada dengan yang disampaikan Santrock (2007:345) yang menyampaikan kreativitas merupakan kemampuan dalam berfikir merumuskan ide-ide baru dan menggabungkannya dengan ide-ide lama kemudian mengkombinasikannya sehingga terbentuk sebuah pemahaman. Dalam hal ini kemampuan berfikir tersebut digunakan dalam menyelesaikan permasalah-permasalahan yang dihadapi seseorang di lingkungan sekitarnya. Secara umum, penting bagi seorang guru untuk selalu menumbuh kembangkan tingkat kreativitas anak demi mempersiapkan perkembangan zaman yang semakin maju.

\section{SIMPULAN}

Perkembangan zaman menuntut manusia untuk selalu berbenah dan senantiasa selalu belajar mengikuti perkembangan zaman tersebut. Perubahan zaman sangat berpengaruh dalam dunia pendidikan, tak terkecuali pendidikan anak usia dini. Peserta didik dan guru dituntut untuk saling bekerja sama untuk senantiasa berpikir kritis, inovatif dan kreatif. Salah satunya pengaplikasian permainan loose parts untuk anak usia dini, karena permainan ini sangat mendukung dan dapat meningkatkan kreativitas yang dimiliki oleh setiap individu.

\section{DAFTAR PUSTAKA}

Daly, L., \& Beloglovsky, M. (2014). Loose parts: Inspiring play in young children(Vol. 1). Redleaf Press.

Haughey, S. (2017). Loose Parts: A Start-Up Guide. Fairy Dust Teaching.

Juhaeni, Safaruddin, R Nurhayati, \& Aulia Nur Tanzila. (2020). Konsep Dasar Media Pembelajaran. JIEES : Journal of Islamic Education at Elementary School, 1(1), 3443. https://doi.org/10.47400/jiees.v1i1.11.

Juhaeni, J., Ludiawati, W., Safaruddin, S., Laili, L. N., Ulfa, L. Z., \& Ambarwati, P. (2020). Kesantunan Berbahasa pada Anak Melalui Pembiasaan. JECED: Journal of Early Childhood Education and Development, 2(2), 117-123.

Novita E, N,. (2020) . Pembelajaran Berbasis Loose Parts Untuk Menigkatkan kreatifitas Anak. Jurnal Ilmiah Kajian Ilmu Anak dan Media Informasi AUD

Nugraheni, A. D. (2019). Penguatan Pendidikan Bagi Generasi Alfa Melalui Pembelajaran Steam Berbasis Loose Parts Pada Paud. Seminar Nasional Pendidikan Dan Pembelajaran 2019, 512-518.

Mirabella, D, W, P., Ismatul, H., Nila, K. (2020) Loose Parts Play Merangsang Kemampuan Main Pembangunan Anak Usia Dini Di Era Society 5.0. Fakultas Ilmu Pendidikan, Universitas PGRI Semarang

Nurjanah, N. E. (2020). Pembelajaran STEM berbasis Loose Parts untuk Meningkatkan Kreativitas Anak Usia Dini. JURNAL AUDI: Jurnal Ilmiah Kajian Ilmu Anak Dan Media Informasi PAUD, 5(1).

Puspita, W. A. (2019). Penggunaan Loose Parts dalam Pembelajaran dengan Muatan STEM. Kepala BP PAUD Dan Pendidikan Masyarakat Jawa Timur Penasehat Kepala Seksi Informasi Dan Kemitraan, 17.

Safaruddin, S., Ibrahim, N., Juhaeni, J., Harmilawati, H., \& Qadrianti, L. (2020). The Effect of Project-Based Learning Assisted by Electronic Media on Learning Motivation and Science Process Skills. Journal of Innovation in Educational and Cultural Research, 1(1), 22-29.

Safaruddin, Degeng, I. N. S., Setyosari, P., \& Murtadho, N. (2020). The effect of PJBL with WBL media and cognitive style on students' understanding and science- 
integrated concept application. Jurnal Pendidikan IPA Indonesia, 9(3). https://doi.org/10.15294/jpii.v9i3.24628

Serli M., Zahratul Qalbi \& Rafhi Febryan Putera (2020). Efektivitas Kemerdekaan Belajar Melalui Bermain Terhadap Karakter Anak TK Baiturridha Kabupaten Padang Pariaman. Jurnal ilmiah potensial, 2020, vol. 5 (2), 83-90.

Siti W,. Adriana, R, P,. Novita, E, N,. DKK. (2020) Pemanfaatan Loose Parts Dalam Pembelajaran Steam Untuk Anak Usia Dini. Early Childhood Education and Development Journal.

Siti Wahyu, N, Andriani, R, P,. Dkk (2019). Efek Metode STEAM pada Kreativitas Anak Usia 5-6 Tahun. Jurnal pendidikan anak usia dini.

Titania W, P., \& Anik, L. (2020). STEAM Based Lerning Strategies by Playing Loose Parts for the Achievement of 4C Skill in Children 4-5 Years. Universitas Nusantara PGRI Kediri. 